\title{
Könyvszemle
}

SIPOS JÚLIA GONDOZÁSÁBAN

\section{IRIGYSÉG, KIBESZÉLÉS, ROSSZINDULAT}

Almási Kitti klinikai szakpszichológus monográfiájában biztos kézzel nyúl egyik legrégebbi tabunkhoz, az irigység sokoldalú, ám mindenekelőtt ellentmondásos, gyakran meg is tagadott érzéséhez. A szerző bevallott célja, hogy az olvasó fogadja el: időnként minden emberben megjelenik ez az érzés. Ezen túl azonban részletesen bemutatja annak a lehetőségét is, hogyan lehet konstruktívan gazdálkodni ezzel a helyzettel, milyen forrásokat találhat benne az egyén a személyes fejlödéshez, és leír olyan megoldásokat, melyek ismeretében jobban megóvhatjuk magunkat mások irigységétől is. Annak meglétét és intenzitását nem tagadva, hanem megértve - hogy kezdhessünk valamit vele.

A szerző monográfiájában az egyéni aspektusok és a személyközi viszonyok felől is közelít tárgyához: a téma meghatározása, evolúciós vonatkozású elhelyezése és müködésmódjának leírása után külön fejezetet szentel Az irigy gyerek és Az irigy szülö bemutatásának is. Könyvéböl megértjük, hogy az irigység menynyiben irracionális: nem azért kívánjuk a tárgyát, mert szükségünk van rá, hanem mert a másik rendelkezik vele. Ahogy a szerző fogalmaz: „...ha hasonló körülmények közül indulunk, és a másik így köröz le minket egy számunkra is fontos területen, akkor nincs megnyugtató magyarázat, és sokkal jobban birizgál minket a gondolat, hogy nekünk is lett volna esélyünk, mi is lehetnénk most ott, ahol ö van. De nem mi vagyunk... És máris belobbanhat az irigység, melynek kulcsmondata: Miért ő, és miért nem én?"

A szerző a mindennapok egyik legambivalensebb jelenségének feltárására vállalkozott: az irigységgel mindenki találkozik, ám önnön irigységét kevés ember vallja be magának, legtöbben a rájuk irányuló támadásra panaszkodnak. Interkulturálisan is értelmezhetö: mivel mi, magyarok történelmileg ambivalensen viszonyulunk mások sikeréhez (ha a recenzió terjedelme megengedné, a panaszkultúrától a sarckommunikációig számos releváns fogalom lenne ide beemelhetö), ezért az irigységnek is kitüntetett szerepe van a társas kapcsolatainkban. Az egyéni és az interperszonális megközelítés után Az irigység mint teher és Az irigység provokálása című fejezetek a társadalmi reflexiókat mutatják be és értelmezik. 
Ám az irigység nemcsak bennünk, hanem közöttünk is lakozik. Személyes interakció eredménye, a társas networkbe ágyazva jelenik meg. Nem annyira annak alapján ítéljük meg anyagi helyzetünket, hogy mennyit keresünk és fogyasztunk, hanem hogy mennyit keresünk és fogyasztunk a networkön belül a többiekhez képest. Az irigység tehát hálózati alapokról is induló társas szenvedély. Szent Tamás szerint saját lényünk megfogyatkozása, miközben a másik nem lesz több. Kapcsolati mechanizmus - hálózatban zajlik az irigykedés, s mivel kapcsolati és viszonyító jellegü, feltételezi az összehasonlítást. Ha ö gazdagabb nálam, akkor szegény vagyok? Az ember a saját értékeit a másikéból kiindulva értékeli, vagyis ritkán tudja élvezni, amije van, és gyakran szenved attól, ha társa - testvére, barátja, munkatársa - tehetősebb vagy sikeresebb. Az összehasonlítás természetes hajlama a társas lét meghatározó struktúrája - egyúttal az irigység gyökere. Amikor az egyén veszteség gyanánt éli meg a másik javait, eredményeit, és ezt a narcisztikus sérülést a tehetetlenség érzése is kíséri, amiből az irigység ered.

Az irigység evolúciósan kódolt érzelem. Túlélésünket szolgáló ösztönként arra irányult, hogy a javakat, melyekkel az egyed nem rendelkezik, meg kell szereznie a fajtársától, ha erős akar lenni. Ahogy szocializálódunk, változnak attitüdjeink is, de csak lassan múlik - és sosem teljesen - a magunkra irányuló negatív érzés, mely felveti a kérdést: nekünk miért nem sikerült ugyanazt elérni, mint a másiknak. Agresszív versengés is fakadhat belöle, pozitív késztetés is, mely önmagunk meghaladására sarkall. S itt érkezünk el a konstruktív fejlődés lehetőségéhez, hiszen negatív aspektusai mellett az irigység azt is megmutatja, miben fejlődhet, juthat előbbre az ember.

Az irigység egyetemes és komplex, ám rejtőzködő érzelem. A szerző szellemes példájával élve: az igazi barát nem annyira a bajban, mint inkább a pozitív fordulatok megélésében mutatkozik meg. Nehéz helyzetekben sokan színlelik az elvárt empátiát, akár valós segítségnyújtás nélkül, az igazán szerencsés helyzetekben azonban roppant árulkodó, hogy milyen érzés kerekedik felül az érintettekben: mennyire őszintén örül mások sikerének? Aki az irigységtől szenved, érveket konstruál a másikkal kapcsolatban, hiszen ha a hozzá hasonló elismertebb vagy boldogabb nála, az azt jelentheti, hogy vele van a baj. „Jól helyezkedik, de alapvetően csak egy felszínes ember.” „Nem is akkora dolog megírni egy ilyen tanulmányt." Megkezdődik a vágyott tárgy értékeinek tagadása, és így az irigykedő egyén megszabadítja magát a tehetetlenség szinte elviselhetetlen frusztrációjától. Így válik az irigység az önigazolás mechanizmusává, és az önbecsapás termékeny forrásává. Játszmává, ahol a résztvevők csak egymás kárára nyerhetnek, így magában hordozza saját büntetését is.

A jól megválasztott esetleírásokkal illusztrált mủ egyik kulcsfejezete $\mathrm{Az}$ illúziók világa. A közösségi médiában ma jóval több szereplő kommunikál, mint évtizedekkel ezelőtt, és egyre több új technológiai lehetőség támogatja az észlelés 
és a torzítás folyamatait. Almási Kitti számos példával érzékelteti, hogyan vált a Facebook másfél évtized alatt az irigység megszaladásának terepévé, egyidejüleg a depressziót és a boldogtalanság érzését is jelentősen fokozva.

Az irigység evolúciós és morális értelemben is kultúránk centrális jelensége. A fösvény a birtoklást, a rest a semmittevést, a torkos, a buja ember a test gyönyöreit élvezi, a gőgös önnön kiválóságát, a haragos pedig az agressziót - az irigy ember viszont soha nem lesz elégedett. A hét föbün közül ez az egyetlen élvezet nélküli.

(Almási Kitti: Irigység, kibeszélés, rosszindulat. Budapest: Kulcslyuk Kiadó, 2018, 213 o.)

Szvetelszky Zsuzsanna szociálpszichológus 